Vol. 4, No. 4, 2019

\title{
ESTIMATION OF TECHNOGENIC LOAD ON THE SURFACE WATER OF THE NORTH-WESTERN BLACK SEA COAST REGION
}

\author{
Angelina Chugai, Oksana Dzhura \\ Department of Environmental Science and Environmental Protection, \\ Odessa State Environmental University, \\ 15, Lvivska Str., Odessa, 65016, Ukraine \\ avchugai@ukr.net
}

https://doi.org/10.23939/ep2019.04.167

Received: 03.09.2019

(C) Chugai A., Dzhura O., 2019

\begin{abstract}
The paper considers the main sources of anthropogenic pollution of the surface waters of the North-Western Black Sea Coast regions. The level of anthropogenic loading on the surface water by the volumes of sewage and pollutant discharges into the water objects is estimated.
\end{abstract}

Key words: surface water, discharge, module of technogenic load.

\section{Introduction}

The main reason for the unsatisfactory quality of natural water in the regions of Ukraine is their pollution due to the discharge of large amounts of wastewater containing pollutants in its composition. Quite acutely, this problem appears in the regions of the North-West Black Sea Coast (NWBSC), which geographically include the Odesa, Mykolayiv, and Kherson regions.

In general, the NWBSC regions are included in the list of regions with limited reserves of freshwater resources. This is especially true for the Mykolayiv and Kherson regions. The wastewater discharge in each of the regions is carried out by a significant number of enterprises. Recently, enterprises in a housing and communal sector, which in most cases carry out discharges without complying with the requirements, have been the main pollutants.

\section{Theoretical part}

The materials of the Regional reports, Environmental passports and statistical reporting on the volumes of sewage and pollutant discharges in 2012-2017 were used in the work as input data.
One of the indicators of the total technogenic load is a technogenic load module $\left(M_{T}\right)$, which is defined as a sum of weight units of all types of wastes (solid, liquid, gaseous) of industrial, agricultural and communal objects for a year, attributed to an area of an administrative district or areas within which these objects are located, measured in thousands $\mathrm{t} / \mathrm{km}^{2}$ per year. As noted in paper [1], the technogenic load module in the majority of cases is represented by a significant list of indicators characterizing the impact on individual components of the environment. Taking into account the principle of determination of the $M_{T}$, we suggested estimating the level of the technogenic load module on the surface water based on the calculation of the module of technogenic load on water objects $\left(\mathrm{M}_{\mathrm{wo}}\right)$, which is defined as the volume of wastewater (pollutant) discharges into the surface water objects in thousands $\mathrm{t} / \mathrm{km}^{2}$ per year. A similar principle was used by the authors to assess the level of an anthropogenic loading on the air basin [2, 3].

\section{Results and discussion}

\section{Estimation of technogenic load on the surface waters of the Odessa region}

The analysis of technogenic load on the surface waters of the Odesa region was previously made in the work [4].

The dynamics of water intake, water consumption and discharges of reverse water in the Odesa region in 2015-2017 was analyzed. It was estimated that the largest volumes of water intake are noted for the surface sources. Moreover, their volumes make up almost $95 \%$ of the total water intake in the region. In using water for different types of needs the use of water for irrigation is in the first 
place. Also, a significant amount of water is used for household and drinking needs. Minimum values are noted for the use of water in the agricultural sector. Reverse water discharge is carried out mainly into the surface water objects. About $40-50 \%$ of reverse water discharged are characterized as "regulated purified". A slight decrease in the volume of reverse water discharges in general for the period from 2015 to 2017 is noted. According to the types of economic activity, $92 \%$ of the resources are used by the housing and utilities sector [4].

On the territory of the Odesa region, there are 132 enterprises that discharge wastewater into the surface water bodies, including 24 farms, which discharge it into the irrigation systems channels. 70 enterprises have approved projects on the norms of maximum permissible discharges (MPD) of pollutants, 62 enterprises do not have MPD projects. The main polluters are "Infoxs" Ltd., "Infoxvodokanal" branch, Communal enterprise "Illichivskvodokanal", Communal enterprise
"Vodokanal" of the city of Artsiz, "Kotovskvodokanal", Communal Enterprise "Bilgorod-Dniestervodokanal", "Teplodarvodokanal" etc. according to [5]. That is, the main polluters of water objects are, first of all, enterprises of housing and communal services.

The results of the estimation of the level of anthropogenic load on the surface water based on the calculation of the $M_{W O}$ index according to the volumes of wastewater and pollutant discharges are given in Fig. 1. As can be seen, the value of the $M_{W O}$ for different indicators varies considerably. In terms of wastewater discharges, there is a tendency towards a gradual decrease in the level of technogenic load from 2012 to 2016. In 2017 the $M_{W O}$ index remained at the level of 2016. In terms of the volumes of pollutant discharges, the $M_{W O}$ index also decreased from 2012 to 2016. However, the maximum, which almost 2 times exceeded the level of technogenic load in 2012, was noted in 2013.

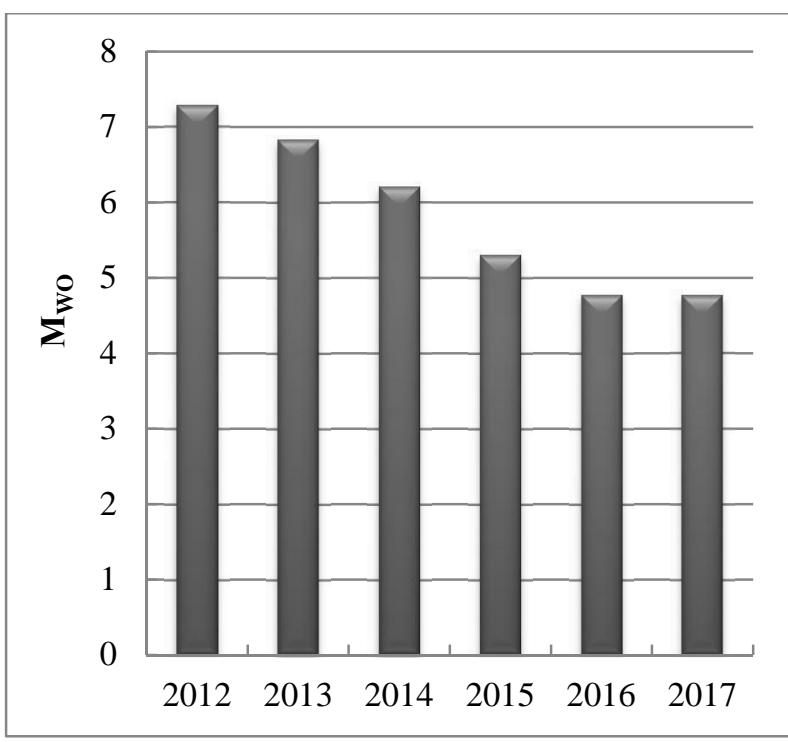

a

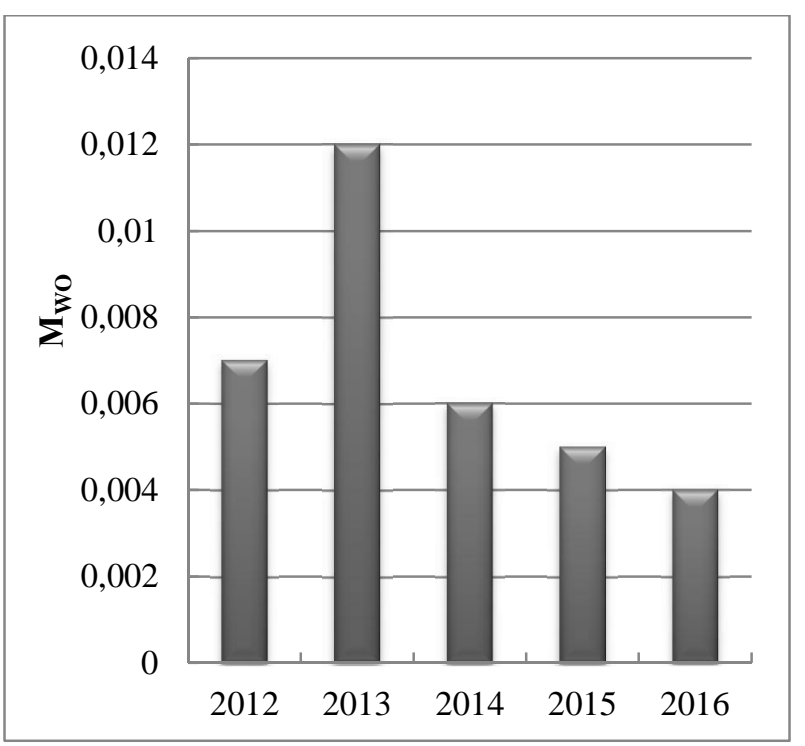

Fig. 1. The value of a $M_{W o}$ index by the volumes of waste water (a) and pollutants (b) in the Odessa region in 2012-2017 [4]

It should be noted that a reduction in the $M_{W O}$ index by the volumes of wastewater discharges is logical since, as noted above, there is dynamics of a total volume reduction of discharges. The same conclusion can be made for the $M_{W O}$ index in terms of pollutant discharges. Estimation of technogenic load on the surface waters of the Mykolaiv region

The Mykolayiv region belongs to the basins of the Southern Bug, the Dnipro, and the Black Sea rivers. There are 121 rivers and beams in the region including six medium rivers (the Kodima, the Sinyukha, the Chorny Tashlyk, the Chichiklya, the Ingul, the Ingulets), and one large river - the Southern Bug. The surface water resources of the region, except for rivers, include lakes, reservoirs, ponds, and marshes [6].

Fig. 2 gives information on the dynamics of water intake from different sources for 2010-2017. It is clear that until 2014, there was a constant increase in water intake due to increased water intake from the surface sources. In 2015 water intake decreased almost to the level of 2010. The volumes of water intake taken from the underground sources for this period almost has not changed.

According to the data [6], water consumption for production needs is the largest. The dynamics of water 
use for different needs is shown in Fig. 3. The analysis of the above figure shows that during the study period the use of water for irrigation purposes increased, and for household drinking needs it decreased, substantially for agricultural use (by an order of magnitude).

The most water-consuming sectors of the economy in the Mykolayiv region are industry, power industry, and agriculture. Fig. 4 shows the dynamics of contaminated wastewater discharges into the surface water objects in the Mykolayiv region. According to the data they are characterized as insufficiently cleaned. There is no sewage discharges without purification. As can be seen from Fig. 5, during the study period, the volumes of contaminated wastewater discharges decreased. It should be noted that total water intake, as noted above, increased in 2010-2014.

The main pollutants of water bodies according to [6] are "Mykolayivvodokanal", Communal Enterprise "Olshanske" (the Mykolayiv region), Communal enterprise "Pervomaiskyi Vodokanal", Communal enterprise "Prybuzke" (Novaya Odesa city), Communal enterprise "City Vodokanal" (Bashtanka) and Communal Enterprise "Ochakivvodokanal".

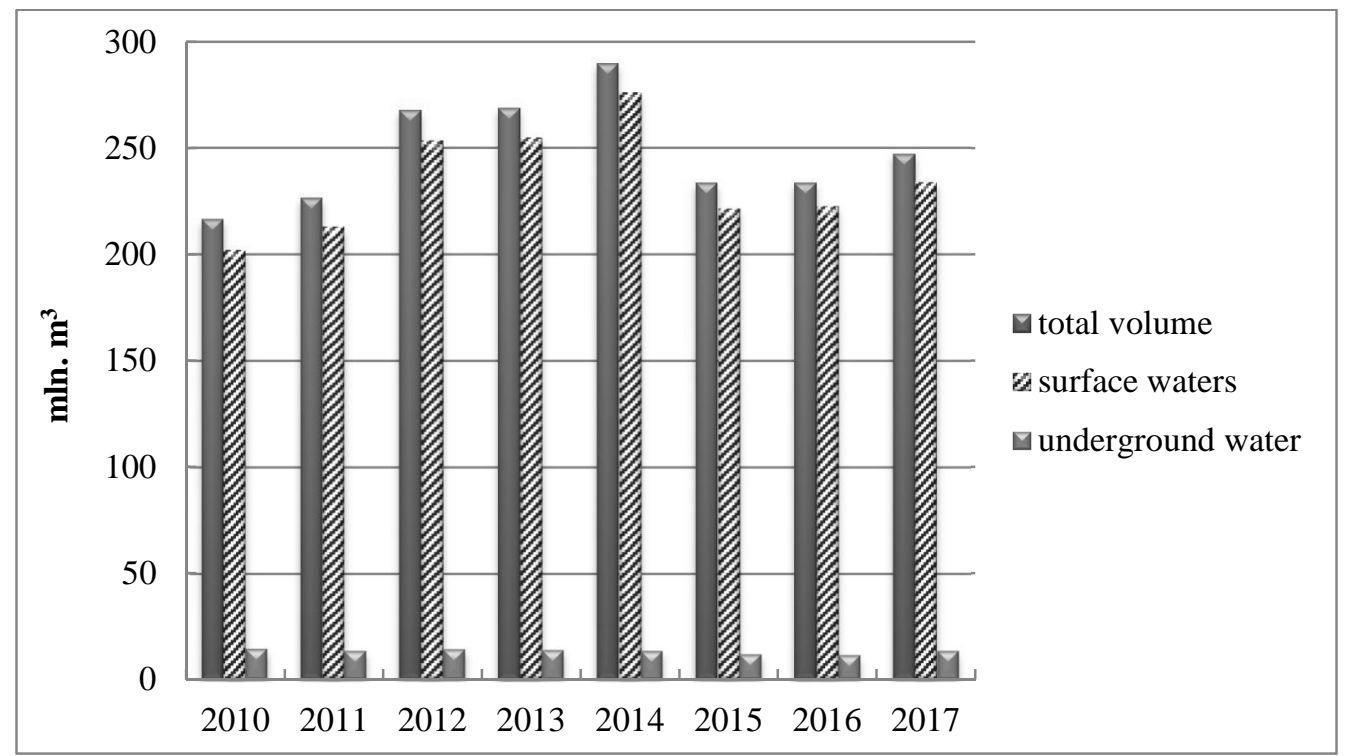

Fig. 2. Dynamics of water intake in the Mykolaiv region in 2010-2017 [6, 7]

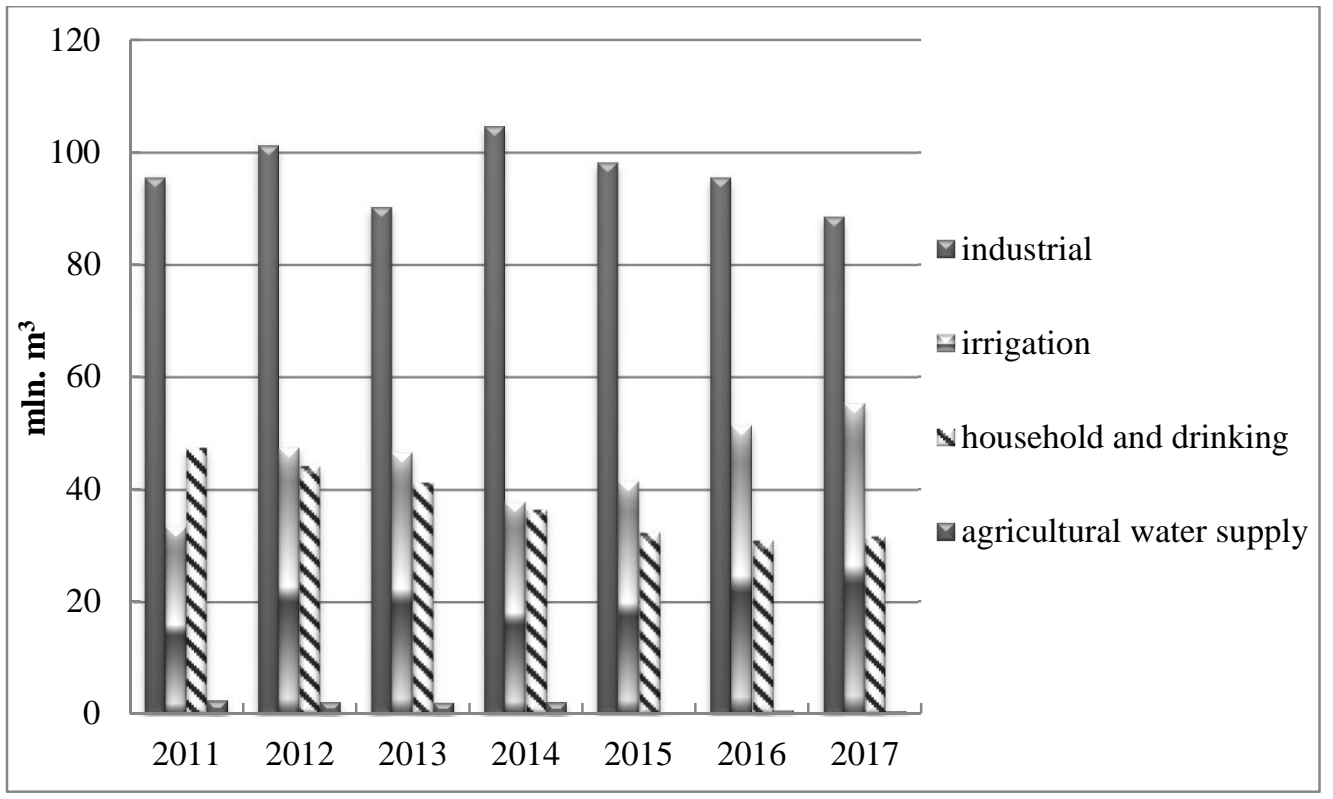

Fig. 3. Dynamics of water use for different needs in the Mykolaiv region in 2011-2017 [6, 8] 


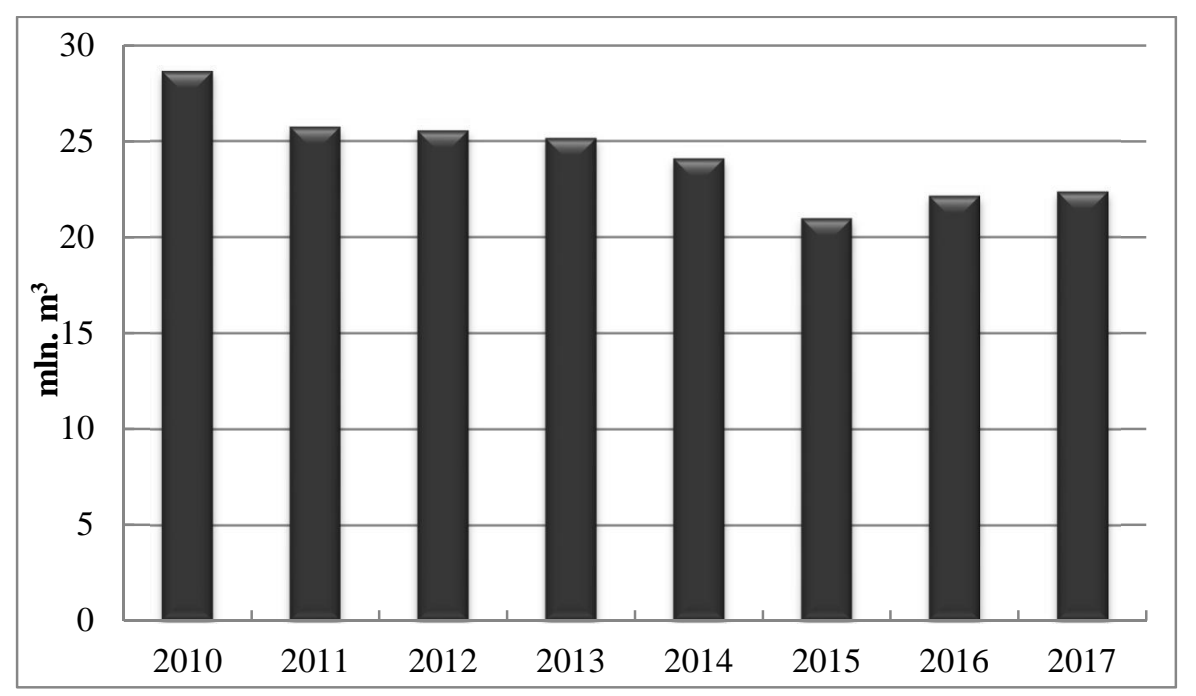

Fig. 4. Dynamics of contaminated waste water discharges into the surface water objects of the Mykolaiv region in 2010-2017 [6, 7]

Fig. 5 shows the dynamics of changes in the $M_{W O}$ index according to [9-11] for 2012-2017 based on the indexes of wastewater and pollutant discharges. As can be seen in terms of sewage discharges, the maximum value of $M_{W O}$ was noted in 2014. In 2015 the $M_{W O}$ index decreased significantly and remained at the same level till
2017. In terms of pollutant emissions, the $M_{W O}$ index for the entire study period remained unchanged. That is, at a significant reduction of the amount of wastewater discharges into the water facilities in the Mykolayiv region from 2015, the amount of the pollutants in their composition remained almost unchanged.

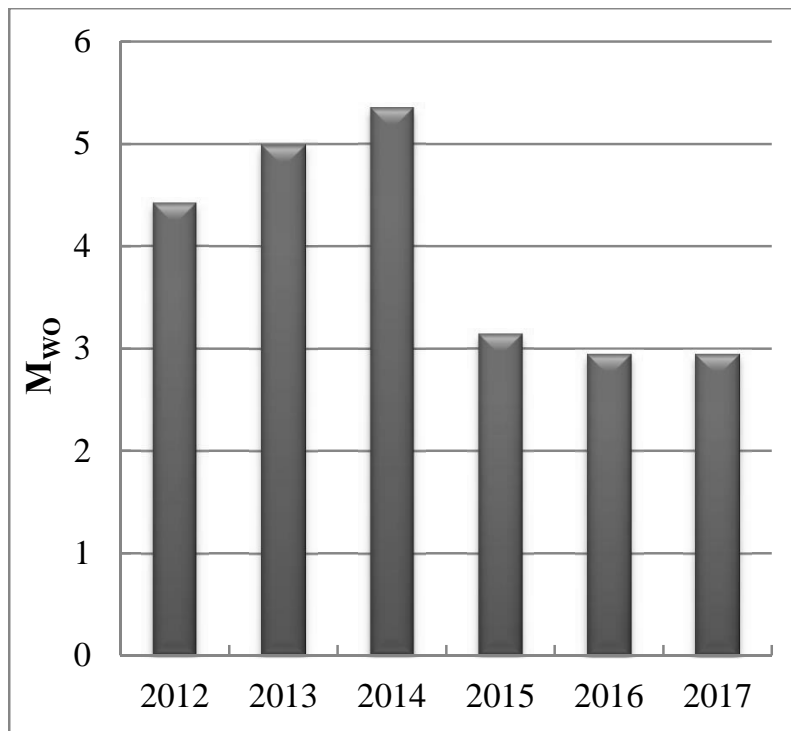

a

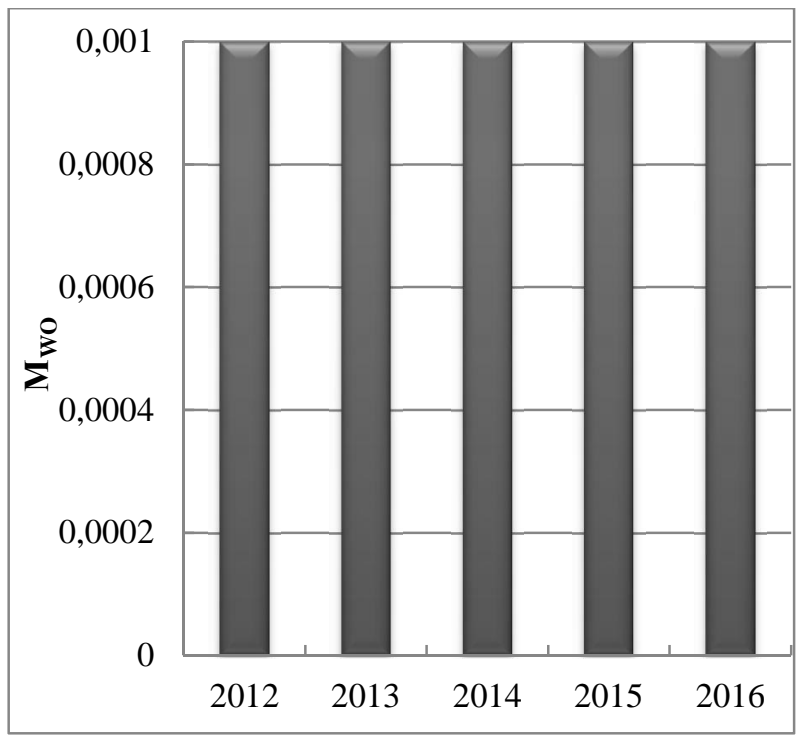

b

Fig. 5. The value of the $M_{w o}$ index by the volumes of waste water (a) and pollutants (b) in the Mykolaiv region in 2012-2017

Estimation of technogenic load on the surface waters of the Kherson region

The analysis of the sources of anthropogenic influence on surface waters in the Kherson region has been made in work [12].
In the Kherson region, there are 24 small rivers, 693 lakes, one reservoir (Kakhovka), and 22 estuaries. The main river in the Kherson region is the Dnieper. The waters of the Dnipro River feed the Kakhovka Mainland and the North-Crimean Canal. Water resources of the region also include underground water, which is most intensively used in the steppe zone [13]. 
If we compare the volumes of water in the NWBSC regions (Fig. 6), this indicator is maximum in the Kherson region.

The increase in water intake in the Kherson region from 2015 to 2017 is noted. However, the volume of reverse water discharges in 2017 remained at the level of 2015. By the types of economic activity, agriculture is the most water-consuming sector of the economy (more than $90 \%$ of water consumption).

The main pollutants of the water objects in 2017 were 4 enterprises, the largest of which is the Communal
Enterprise "Clearing Facilities" of the Skadovsk City Council and "Rice of Ukraine" Ltd.

Fig. 7 shows the dynamics of changes in the $M_{W O}$ index according to the data [14-16] for 2012-2017 based on the indexes of wastewater and pollutant discharges. In terms of wastewater discharges the minimum value of the $M_{W O}$ index was noted in 2014. In other years, the level of technogenic load on the parameters of wastewater discharges almost did not change. According to the volumes of pollutant emissions, there is a constant decrease in the $M_{W O}$ index from 2012 to 2017. That is, the amount of pollutants in wastewater is decreasing over the years.

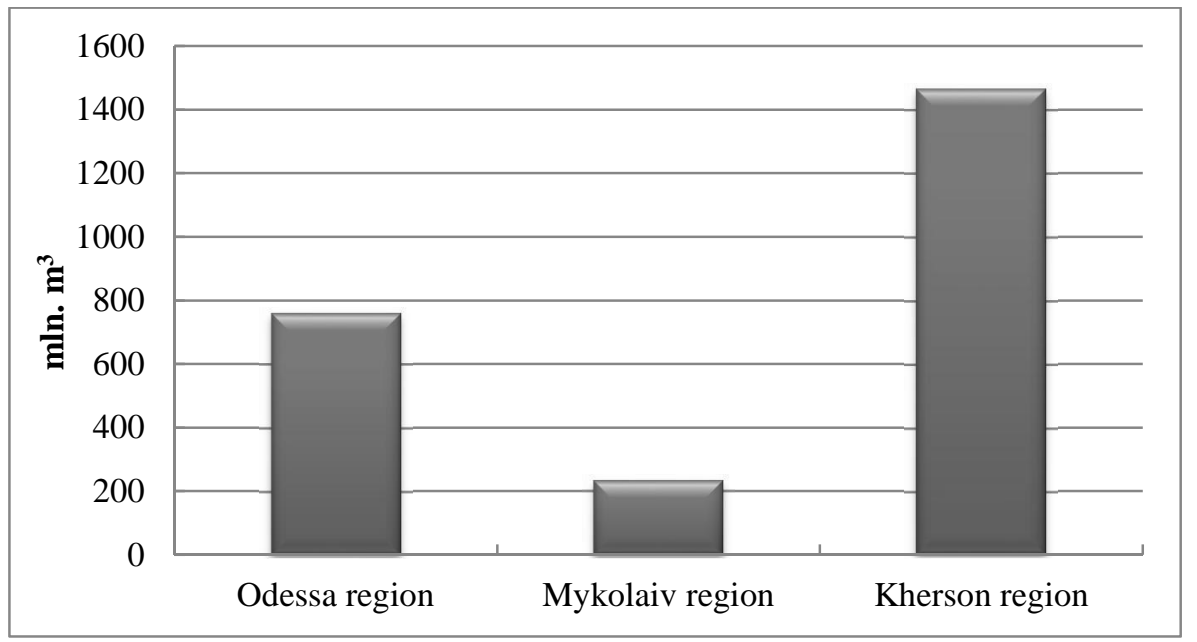

Fig. 6. Volumes of water intake in the regions of the North-Western Black Sea Coast regions in 2015 [13]

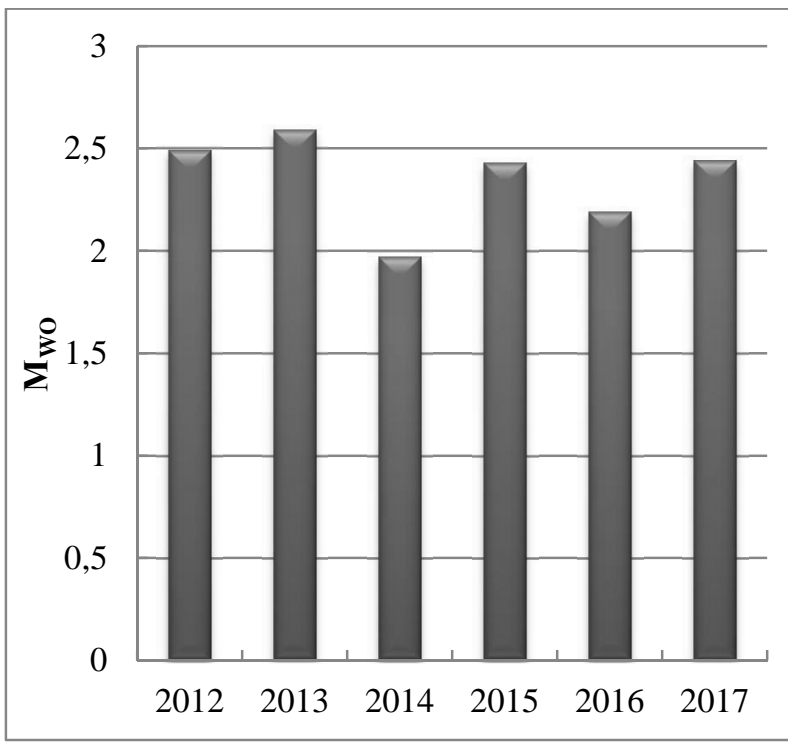

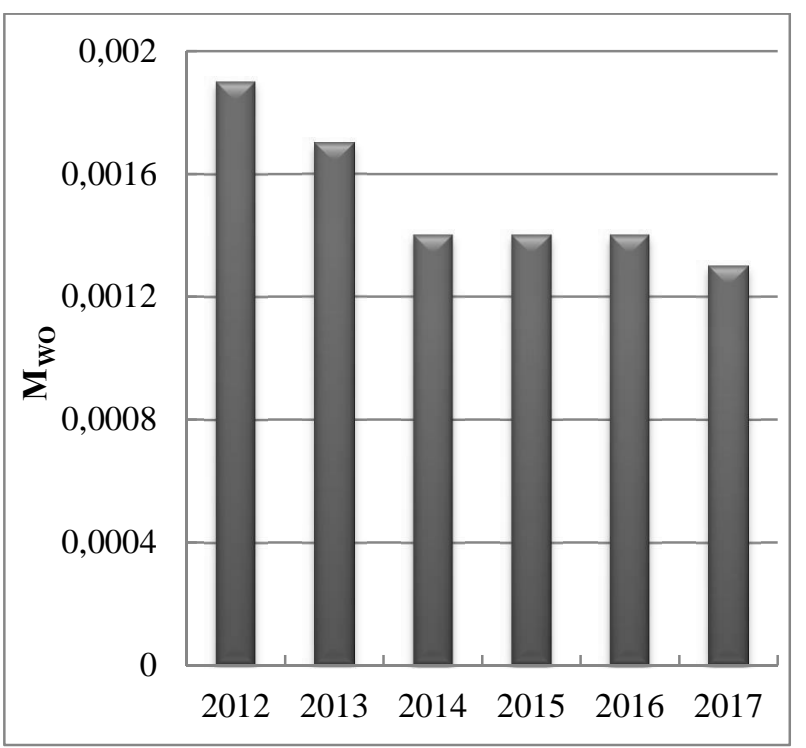

Fig. 7. The value of the $M_{W o}$ index by the volumes of waste water (a) and pollutants (b) in the Kherson region in 2012-2017

\section{Comparative analysis}

The comparative analysis of technogenic load on the surface water objects in the NWBSC regions was made (Figs. 8, 9).
Fig. 8 shows that the maximum values of wastewater discharges and the $M_{W O}$ index among the regions of NWBSC are noted for the Odesa region. However, there is a decrease in the relative indexes of $M_{W O}$ for the Odesa region and an 
increase for the Mykolayiv region. If we compare the Mykolayiv and Kherson regions, then with almost identical indicators of wastewater discharges, a level of technogenic load on the Mykolayiv region is slightly higher.

According to the indicators of pollutant discharges (Fig. 9), the maximum indicators are observed for the Odesa region. Among the other two regions, the pollutant discharges are somewhat higher in the Kherson region, but the level of technogenic load is characterized by the same indicators for the Mykolayiv and Kherson regions.

\section{Conclusions}

As a result of the research, the following conclusions can be made:

- In the Odesa region, the value of the $M_{W O}$ index varies considerably in terms of sewage and pollutant discharges. However, there is a single tendency to reduce the level of technogenic load. This is natural since the dynamics of the reduction in the total volume of discharges is noted.

- In the Mykolayiv region, in terms of wastewater discharges, the maximum value of $M_{W O}$ was noted in 2014. The volume of pollutant emissions was unchanged. That is, at a significant reduction since 2015 , the volume of wastewater discharges containing pollutants in their composition has remained almost unchanged. This indicates an increase in the level of surface water pollution in the region.

- In the Kherson region, in terms of wastewater discharges, the minimum value of the $M_{W O}$ index was noted in 2014. In terms of pollutant discharges, there is a constant decrease in the index. That is, the amount of pollutants in wastewater decreases annually.

- The comparative analysis of technogenic load on the surface water bodies of the NWBSC regions showed that the maximum values of wastewater discharges and the $M_{W O}$ index are noted for the Odesa region. Also, there is a decrease in the relative $M_{W O}$ indexes compared with the discharges indexes for the Odesa region and an increase for the Mykolayiv region. With almost identical indicators of wastewater discharges, the level of technogenic load on the Mykolayiv region is slightly higher than on the Kherson region. Similarly, in terms of discharges of pollutants, the maximum values are observed in the Odesa region. Among the other two regions, the discharges are slightly higher in the Kherson region, but the level of technogenic load is characterized by the same indicators for the Mykolayiv and Kherson regions.

The obtained results are part of the research presented in work [1], devoted to the comprehensive assessment of technogenic load on the NWBSC regions. They are the basis for the development of regional programs aimed at reducing technogenic impact on the environment in the NWBSC regions. The analysis of the literary sources indicates that in order to prevent further pollution of the water objects in the NWBSC regions, there is an urgent necessity to reconstruct municipal wastewater treatment facilities, which in most cases due to unsatisfactory conditions and outdated equipment are among the main pollutants of the surface water.

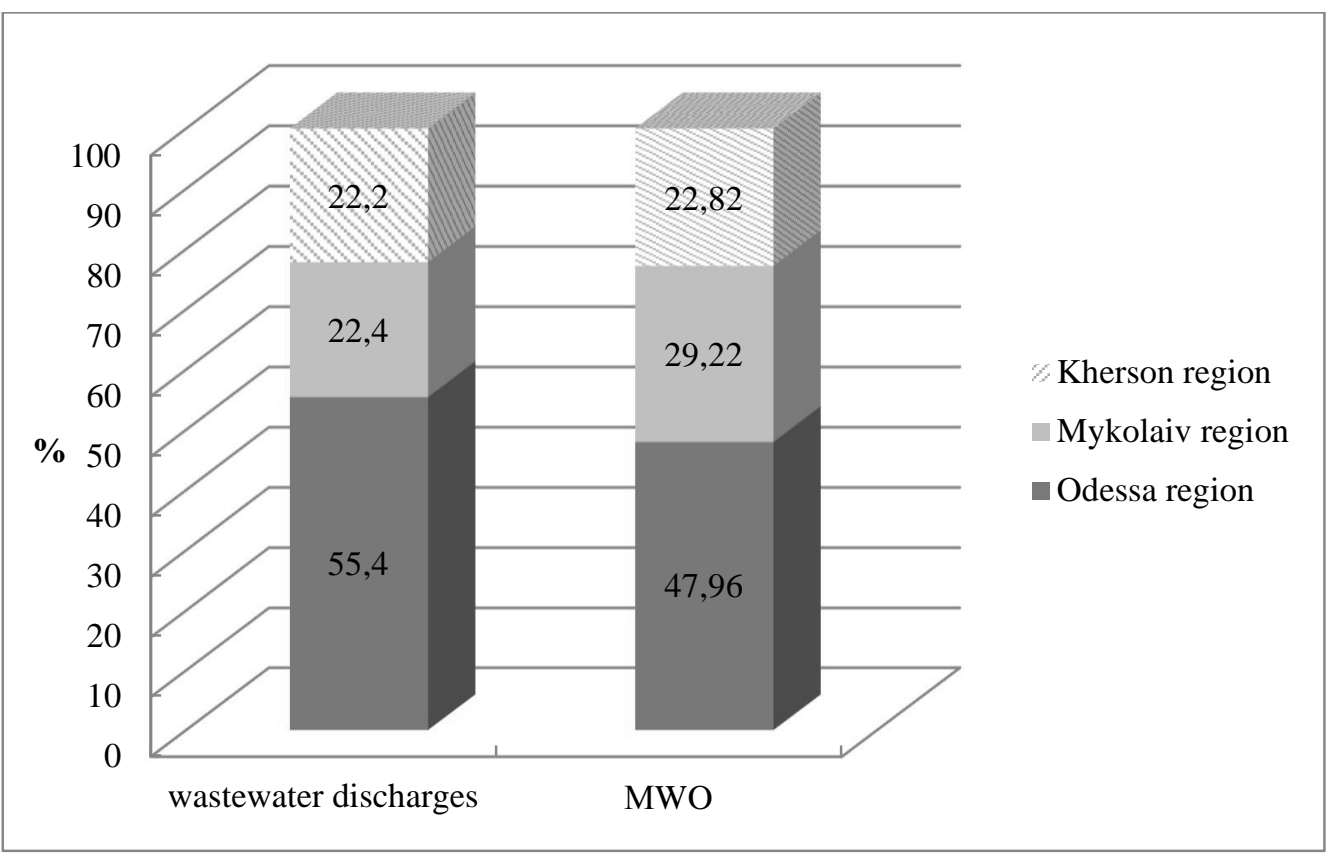

Fig. 8. Comparative analysis of the level of anthropogenic load on the surface water of the NWBSC regions in terms of wastewater discharges (averaging for 2015-2017) 


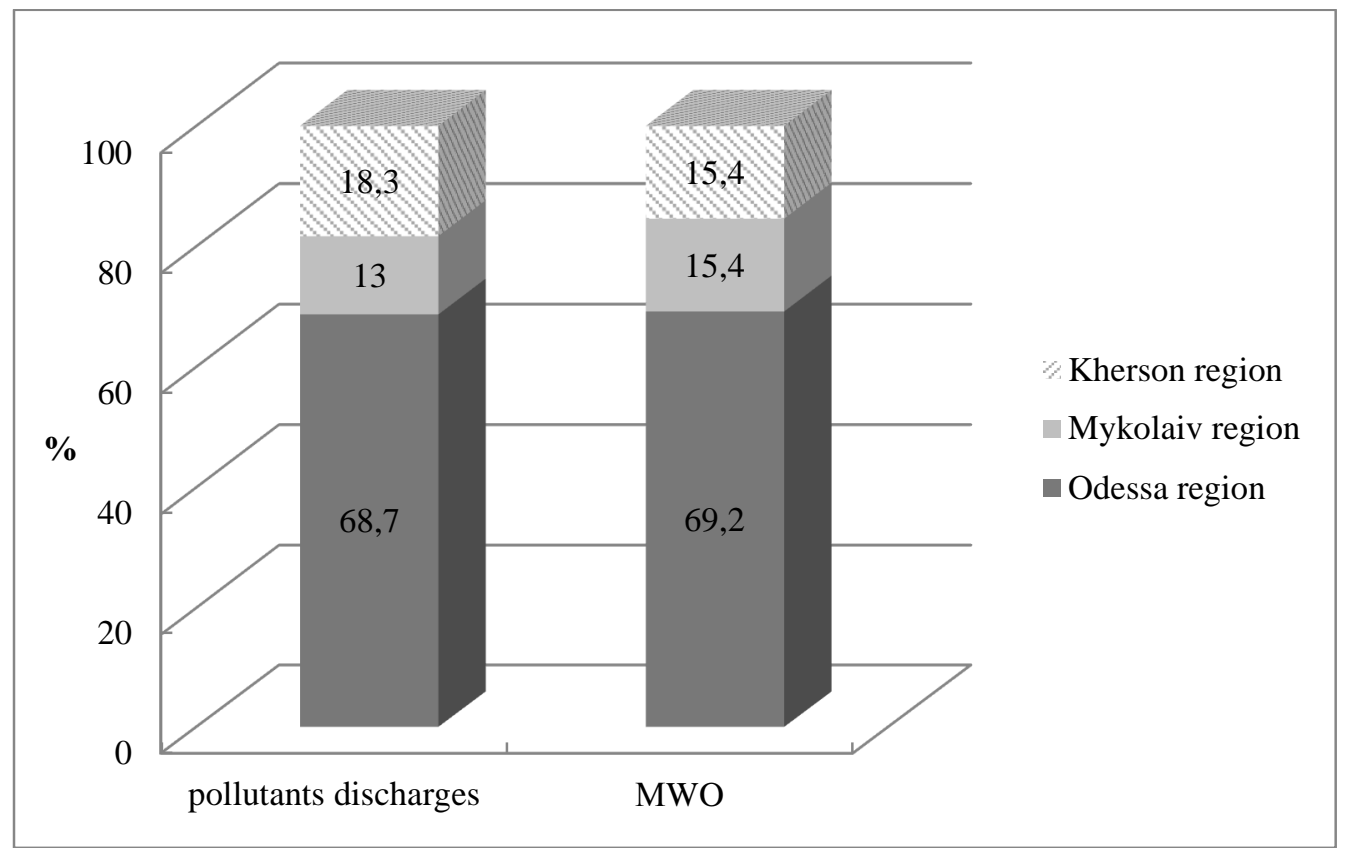

Fig. 9. Comparative analysis of the level of anthropogenic load on the surface water of the NWBSC regions in terms of pollutant discharges (averaging for 2015-2016)

\section{References}

[1] Adamenko O. M., Rudko H. I. Ekolohichna heolohiia. Kyiv: Manuskrypt,1997. (in Ukrainian)

[2] Chugai A., Safranov T., Holik Yu.: International Journal of Engineering \& Technology (UAE), 2018, 7 (4.8), 783.

[3] Chugai A. V., Cherniakova O. I., Bazyka Yu .V.: Visnyk Kharkivskoho natsionalnoho universytetu im. V. N. Karazina, Ser. "Ekolohiia", 2018, 19, 75. (in Ukrainian)

[4] Chugai A. V., Dzura O. S.: Ekolohichna bezpeka, 2018, 2 (26), 59. (in Ukrainian)

[5] Rehionalna dopovid pro stan navkolyshnoho pryrodnoho seredovyshcha v Odeskii oblasti u 2016 rotsi. Odesa, 2017. (in Ukrainian)

[6] Rehionalna dopovid pro stan navkolyshnoho pryrodnoho seredovyshcha v Mykolaivskii oblasti u 2017 rotsi. Mykolaiv, 2018. (in Ukrainian)

[7] Rehionalna dopovid pro stan navkolyshnoho pryrodnoho seredovyshcha v Mykolaivskii oblasti u 2016 rotsi. Mykolaiv, 2017. (in Ukrainian)
[8] Rehionalna dopovid pro stan navkolyshnoho pryrodnoho seredovyshcha v Mykolaivskii oblasti u 2015 rotsi. Mykolaiv, 2016. (in Ukrainian)

[9] Ekolohichnyi pasport Mykolaivskoi oblasti za 2015 rik. Mykolaiv, 2016. (in Ukrainian)

[10] Ekolohichnyi pasport Mykolaivskoi oblasti za 2016 rik. Mykolaiv, 2017. (in Ukrainian)

[11] Ekolohichnyi pasport Mykolaivskoi oblasti za 2017 rik. Mykolaiv, 2018. (in Ukrainian)

[12] Chugai A. V., Dzura O. S.: Naukovyi Visnyk VANO, 2019, 2 (25), 231. (in Ukrainian)

[13] Natsionalna dopovid pro stan navkolyshnoho pryrodnoho seredovyshcha v Ukraini u 2015 rotsi. Kyiv, 2017. (in Ukrainian)

[14] Ekolohichnyi pasport Khersonskoi oblasti za 2014 rik. Kherson, 2015. (in Ukrainian)

[15] Ekolohichnyi pasport Khersonskoi oblasti za 2016 rik. Kherson, 2017. (in Ukrainian)

[16] Ekolohichnyi pasport Khersonskoi oblasti za 2017 rik. Kherson, 2018. (in Ukrainian) 